\title{
Metacognitive Education in Improving Student's Intrapersonal Intelligence
}

\author{
Ubaidillah$^{1}$, Tohir Muntoha ${ }^{2}$, Khomsinnudin $^{3}$, M. Khasanudin ${ }^{4}$ \\ ${ }^{1234}$ Sekolah Tinggi Ilmu Tarbiyah Darul Ishlah Tulang Bawang, Indonesia \\ ubaidillah110194@gmail.com*
}

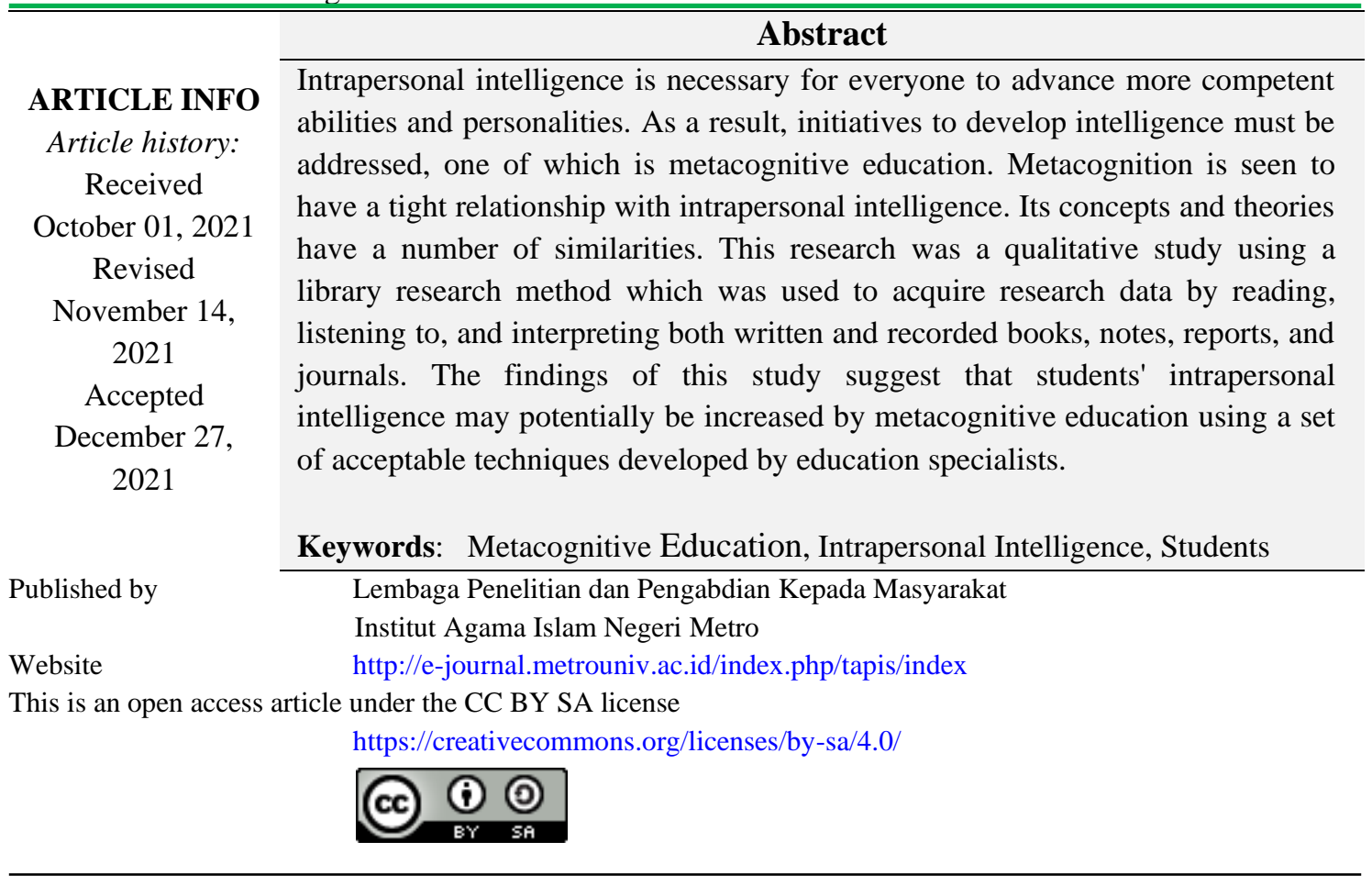

\section{INTRODUCTION}

Education is a deliberate attempt to attain a goal, mainly the elimination of ignorance and the creation of a sequence of life achievements that benefit the needs of many people. Education is a deliberate effort made, either directly or indirectly, to assist children in their growth and maturation. (Bratanata as cited in Astuti \& Zulhakim, 2021, p. 227)

This purposeful endeavor to educate human existence necessitates a great deal of encouragement and support for techniques and ideas that are always in line with the needs of development and advancement of the time. As a result, education must be a dynamic agent of change, that is capable of thinking and acting that is in line with the demands of development and advancement of the times.

Creativity and foresight in utilizing resources through diverse learning approaches must be cultivated and deployed. The enhancement of students' cognitive abilities is one method that may be used to increase learning achievement. In this method, children are taught to grasp concepts through constructive stages.

The purpose of this study was to describe the findings of an analysis on the significance of metacognitive education in improving students' intrapersonal intelligence. The intended outcomes include a description of the information pattern and techniques to imply students' metacognitive so that they can develop their Intrapersonal intelligence. 


\section{METHOD}

This study is a sort of qualitative study that includes a descriptive data presentation. The literacy method (Library Research) was employed to collect data, which is defined as research that investigates or critically assesses a knowledge, concept, or discovery in a document, book, journal, or other sources. A literature review, according to Huda (2011), is a study undertaken to answer an issue based on a critical and in-depth examination of relevant literature sources. Zed clarified that library research is confined to library collection items exclusively, in which field research is not required. (Zed as in M. Sari \& Asmendri, 2020, p. 42)

As a result, library research may be defined as research that collects data through reading, listening to, and evaluating a variety of books, photographs, notes, written reports, and reports of sound and video recordings. It's also known as library research, according to Sutrisno Hadi, since the data or study materials utilized to complete the research originate from libraries in the form of dictionaries, papers, encyclopedias, journals, and other sources. (Sutresno Hadi as in Harahap, 2014, p. 68)

\section{RESULT AND DISCUSSION}

\section{Theoretical Framework}

Metacognition is a person's capacity to recognize and manage his cognitive features. In Bloom's taxonomy, metacognitive capacity is defined as the ability to regulate six levels of cognitive features, which are divided into stages: memory, comprehension, application, analysis, synthesis, and evaluation. Bloom indicated that the taxonomy currently encompasses six primary classes: knowledge, comprehension, application, analysis, synthesis, and evaluation in his book "Taxonomy of Educational Objectives." (Bloom, nd, p. 18)

Figure 1. The Original Version of Bloom's Taxonomy

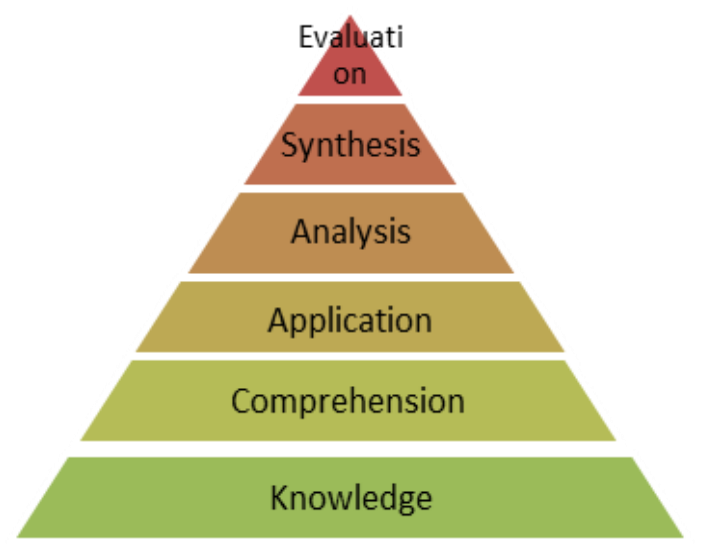

It was also said that the cognitive domain was assessed as being more explicit and sophisticated, as follows: "We first restricted ourselves to the knowledge, intellectual talents, and intellectual skills objectives. This area, which we called the cognitive domain, encompasses the following behaviors: remembering; reasoning; problem-solving; idea development; and, to a lesser extent, creative thinking. We next divided the cognitive objectives into subdivisions, starting with the simplest activity and progressing to the most complicated." (Bloom, nd, p. 15)

The taxonomy notion shown above (the Original Form of Bloom's Taxonomy) is an older version of the taxonomy. David Krathwohl altered the notion of taxonomy in 2000, aligning the synthesis part with evaluation and altering the term to creating. The goal is for students to be able to practice their learning objectives, such as the capacity to create based on their talents, 
during their education after finishing the evaluation. More specific changes are included, such as remembering, understanding, applying, analyzing, evaluating, and creating something based on students' abilities.

Figure 2. Revision of Bloom's Taxonomy

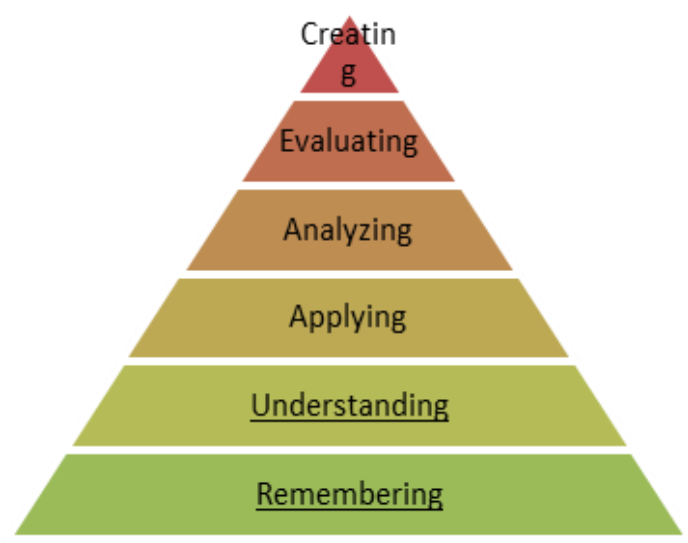

According to (Krathwohl, 2002, p. 214) in his publication, he explained: Application, Analysis, and Evaluation were retained, but in their verb forms as Apply, Analyze, and Evaluate. Synthesis changed places with Evaluation and was renamed Creating. The pyramid graph above depicts changes in the preceding taxonomy domain's structure. The following are some of the changes:

Table 1. The Revision of the Bloom's Taxonomy Domain

\begin{tabular}{|c|c|c|}
\hline \multicolumn{2}{|c|}{ The Term Changes } & The Position Changes \\
\hline Original & Revision & Revision \\
\hline Synthesis & Creating & Changes in position only occur between \\
\hline Evaluation & Evaluating & Synthesis and Evaluation. Synthesis was \\
\hline Analysis & Analyzing & placed to the top of the taxonomy domain \\
\hline Application & Applying & once it was converted to Creating. \\
\hline Comprehension & Understanding & \\
\hline Knowledge & Remembering & \\
\hline
\end{tabular}

Metacognitive is the awareness of oneself, starting with one's strengths, flaws, personal character, and how one learns and performs things. With this knowledge, someone can have a high capacity to solve difficulties because he will pick and go through a succession of problem formulations such as "what am I doing?" "what can and should I do?" and "what objects can assist me to accomplish this work/problem?"

Metacognition can be exemplified in everyday life, for example, "Salma, a high school student, was assigned the duty of developing an idea for a school performance by her teacher. When she returned home, her mother requested her to look after and teach her younger sister to read after school. Her pals arrived to take her to the city amusement park. Salma wonders in this circumstance, "how can she do all of her jobs on time and yet have time to rest?". Salma ultimately came up with a solution after much thought: she would ask a friend to look after her sister and teach her to read while she finished her duty of developing a school performance idea. As a result, she'll be able to attend the city's amusement park with her buddies." 
Not all students, as seen in the case above, have strong metacognitive abilities. Students with low metacognitive abilities will be perplexed about how to fulfil the layers of work they are given, and they may choose to sacrifice or reject one of them, such as declining to care for and teach their younger sister to read because they are too busy or exhausted. Salma, on the other hand, can solve her challenges because of her strong metacognitive powers. As a result, metacognition may be thought of as a way of thinking, i.e., thinking about considering, comprehending, and evaluating ways of thinking to make the best decisions and solve issues.

Intrapersonal intelligence is the capacity to recognize oneself through a sequence of thought processes that culminate in action. Intrapersonal intelligence, according to Suryadi, is the ability to think reflectively, which is a reflective knowledge of one's sentiments and comprehending personal thought patterns. (Suryadi as in Peking \& Utami, 2020, p. 14)

Meanwhile, intrapersonal intelligence, according to Sujiono as cited in (Peking \& Utami, 2020, p. 14), is one's own ability to think reflectively, that is, reflective knowledge of one's own sentiments and conceptions of thought. Intrapersonal intelligence, as defined by (Lwin et al in Juatiningsih \& Suendarti, 2019, p. 41) is intelligence about oneself. Thinking, goal-setting, considering reflection, self-assessment, and introspection are examples of intrapersonal intelligence activities.

Social engagement or social experience can help to build self/individual consciousness (intrapersonal) (Suralaga, 2021). The role of parents, instructors, and peers in the development of intrapersonal intelligence are significant. Intrapersonal intelligence can be interpreted through a strong self-concept and self-actualization.

Based on the data given above, it is clear that there is a link between metacognitive theory and intrapersonal intelligence, and that both contribute to the ability to comprehend oneself. The distinction is that metacognitive intelligence is the ability to comprehend one's own cognitive concept, whereas intrapersonal intelligence is the ability to comprehend one's own affective concept. Attitudes, feelings, interests, abilities, emotions, and values are all part of the affective domain.

Children with strong metacognitive abilities will be able to understand what they think or what is on their minds, realize what they don't know and then learn, discover the best answer to difficulties, and understand their own capacities. Students will be able to solve challenges they are having, whether they have problems in learning, social interactions, or defining their identity, with a combination of these competencies.

Gardner explains in the book Frames of Mind:

"I emphasized how intrapersonal intelligence grew out of and was structured around, the individual's "feeling life." If I had to rewrite the relevant sections of Chapter 10 today, I would emphasize the necessity of having a valid model of oneself and being able to draw on that model successfully when making life decisions." (Gardner, 2011, p. xxxvi)

According to Gardner, the ability to self-reflect or be aware of one's own thoughts is critical for a person to have in order to assist oneself in making decisions when faced with life's challenges. Students will begin to think about what they need to know to make a solution to a problem that is in accordance with their own abilities through the concept of "smart work," which is to complete work without burdening themselves in the long run (Juatiningsih \& Suendarti, 2019, p. 41).

Students will gain intelligence in developing their personalities by being conscious of any shift in their mindset. Children with intrapersonal intelligence, according to (Suyadi in Peking \& 
Utami, 2020, p. 15), are more likely to 1) be happy to reflect, 2) often express their goals to others, 3) have high self-confidence, 4) use time well, 5) have high motivation, 6) frequently imagine and think, and 7) be silent when angry as if controlling his emotions.

According to Suyadi's intrapersonal personality tendencies, students who have excellent thinking awareness abilities would score higher on the seven personal criteria. Contemplating, dreaming, motivating, daydreaming, and managing time and emotions all need high thinking awareness abilities, because simply being able to think is insufficient. Students with strong cognitive abilities, such as math ability, ease of memorization, and critical thinking, may not always have strong metacognitive abilities. As a result, metacognitive education is critical for improving students' intrapersonal intelligence.

Students with intrapersonal intelligence are individuals who prioritize feelings and values, as explained by (Munif Chatib \& Alamsyah Said in Ardimen, 2016, p. 115) that learning of children with intrapersonal intelligence is well-conducted through an approach to feelings, values, and attitudes. The emphasis of the intrapersonal intelligence approach is based on the ability to make an accurate perception of oneself (self-individual). As a result, metacognitive education must be supported as a counterweight to feelings-oriented attitude inclinations. According to Gardner, a person's intrapersonal capacities will allow them to recognize and express a complex and diverse set of emotions at the most advanced level. (Gardner, 2011, p. 253).

It is envisaged that students would become assertive, intelligent, autonomous, and creative persons as a result of their capacity to view themselves properly (intrapersonal), which is founded on a systematic-realistic (metacognitive) thinking awareness.

\section{Metacognitive Education Strategies}

Students can engage in metacognitive education by participating in activities that require them to think about what they know, what they care about, and what they are capable of. These exercises will assist students in developing self-awareness of their own abilities and deficiencies, allowing the teacher to give direction, counsel, and assistance to address these shortcomings.

Furthermore, teachers can also provide students the opportunity to reflect on their learning progress so that they can assess their degree of learning achievement. Students will be able to develop a notion of thinking "what should I do?" and "how can I achieve that?" by engaging them in an activity that requires them to constantly reflect on their learning progress. The notion of thinking will therefore inspire creativity in devising solutions to the difficulties highlighted above.

According to Indarini et al., a complex learning system with a mix of contextualization of learning would help students increase their knowledge of different learning. Different thinking techniques will help students establish "what" and "how" thinking frameworks, which are important to develop. (Indarini, Sadono, \& Onate, 2013a, p. 42).

When students become aware of "what are the shortcomings" and begin to investigate "how to address these flaws?" and the notion to devise a strategy emerges, the instructor begins to educate students on how to "Plan" something. Making plans and self-regulation, according to Blakey and Spence, is one of the activities that can help students improve their metacognitive skills. This means getting used to planning learning concepts, organizing thinking patterns, and conducting self-evaluations in order to achieve better learning success. (Blakey \& Spence, 1990, p. 2-3) 
According to Dirkes as cited in (Blakey \& Spence, 1990) metacognitive strategies can be implemented in three basic steps: 1) integrating new information with existing knowledge, 2) sorting and selecting appropriate learning/thinking strategies, and 3) planning, monitoring, and evaluating the learning/thinking process.

Meanwhile, metacognition, according to Kratwohl, is a component of the knowledge dimension of cognitive understanding, which is concerned with patterns of thinking, perceiving, remembering, and understanding. The cognitive dimension process is made up of the following steps: 1) remembering, 2) understanding, 3) applying, 4) analyzing, 5) evaluating, and 6) creating. (Krathwohl, 2002)

To educate establishing awareness of thinking, the following might be used to explain students' metacognitive activities in the form of identification:

Table 2. Students' Metacognitive Activities

\begin{tabular}{|l|l|}
\hline Components & Students' Activities \\
\hline action. & $\begin{array}{l}\text { 1. What prior knowledge can I depend on to assist me in } \\
\text { completing this task? }\end{array}$ \\
& $\begin{array}{l}\text { 2. Where will my thoughts lead me? } \\
\text { 3. What should I do first? } \\
\text { 4. Why am I reading this section? } \\
\text { 5. How long should I complete this task? }\end{array}$ \\
\hline Monitoring or controlling & $\begin{array}{l}\text { 1. How do I do? } \\
\text { actions }\end{array}$ \\
$\begin{array}{ll}\text { 2. Am I on the right path? } \\
\text { 4. What information is important to remember? } \\
\text { 5. Should I move to a different way? } \\
\text { 6. Should I make a step adjustment } \\
\text { related to difficulties? }\end{array}$ \\
$\begin{array}{ll}\text { 1. How well did I perform? } \\
\text { 2. Will the effects of this specific discourse of thought be } \\
\text { more or less than what I expect? } \\
\text { 3. Have I been able to accomplish it in a different way? } \\
\text { 4. Can I use this strategy to solve other issues? } \\
\text { 5. Do I need to return to the original work to complete the } \\
\text { missing component of my understanding? }\end{array}$ \\
\hline
\end{tabular}

As can be seen from the table above, the teacher has the ability to present a stimulus to students in order to prompt them to reply about themselves. The response might take the form of a shift in attitude, queries about how they can improve, or even a suggestion for their personal preparation for finishing the school projects they are now working on.

\section{Metacognitive to Intrapersonal Intelligence}

Intrapersonal intelligence, according to Howard Gardner as an educational and psychological figure best known as the creator of the Multiple Intelligences theory, is the capacity to perceive one's own sentiments, such as joy and sadness, (Gardner, 2011). Students with metacognitive abilities will be able to think about who they are, what they enjoy, what they dislike, what motivates them, and what makes them unhappy and depressed. Students' 
metacognitive skills will also lead them to find answers to their personal difficulties (self problems) as well as remedies to the problem.

In addition, Flavell identified the correlation between intrapersonal intelligence and metacognitive intelligence. Self-awareness, he added, is a crucial component in the formation of metacognitive knowledge. Self-awareness entails understanding one's own strengths and flaws, (Indarini, Sadono, \& Onate, 2013b).

Maryati et al. found a strong association between the intrapersonal intelligence teaching model and students' metacognitive capacities in their research of the correlation between teacher's teaching skills and intrapersonal intelligence on students' metacognitive awareness at SMKN Blitar City (Maryati, Khasanah, \& Maf'ula, 2020).

Self-awareness (intrapersonal), or an individual's ability to comprehend himself or herself, plays a crucial part in the arrangement of Metacognitive intelligence (D. P. Sari, Usodo, \& Subanti, 2018). The survey findings show that even students who have relatively outstanding grades have not been demonstrated to have maximized the evaluation process in self-planning and self-actualization (D. P. Sari et al., 2018). As a result, excellent metacognitive abilities necessitate a balance with intrapersonal abilities, which are individual qualities that help people explore and evaluate themselves.

Our views of others and human connections in this world, according to Krause et al, have a lot to do with our knowledge of ourselves (Krause in Suralaga, 2021). Self-growth is linked to cognitive and emotional development, whereas social and moral development is linked to how we perceive others and how we interpret our interactions with others. (Suralaga, 2021).

\section{CONCLUSION}

Metacognitive awareness is the ability to think about one's own thoughts. This skill can assist students in recognizing the pattern or structure of their own thinking, allowing them to discover their own conceptions. Intrapersonal intelligence, on the other hand, is a self-awareness of one's own sentiments, beliefs, and attitudes, such as considering "what is good and bad for me?" and "what may bring me down and bring me up?" Students' intrapersonal awareness will be conceived and better structured with the help of metacognitive education. Metacognitive abilities that offer detection of significant and factual ideas will improve intrapersonal inclinations that are identical with values and sentiments.

\section{ACKNOWLEDGEMENT}

This is a short text to acknowledge the contributions of specific colleagues, institutions, or agencies that aided the efforts of the authors.

\section{AUTHOR CONTRIBUTION STATEMENT}

The first author is Ubaidillah, an undergraduate lecturer and the Head of LPM at Darul Ishlah High School of Education (STIT), Tulang Bawang. The second author is Tohir Muntoha, an undergraduate lecturer and the Head of Darul Ishlah High School of Education (STIT), Tulang Bawang. The third author is Khomsinnudin, an undergraduate lecturer and Deputy Chair II at Darul Ishlah High School of Education (STIT), Tulang Bawang. The fourth author is M. Khasanudin, an undergraduate student of the Islamic Education Study Program at Darul Ishlah High School of Education (STIT), Tulang Bawang 


\section{REFERENCES}

Ardimen. (2016). Pengembangan Multiple Intelligence Melalui Pembelajaran Integratif Berbasis Games (Model Integrasi Bimbingan dalam Proses Pembelajaran sebagai Upaya Mengembangkan Berbagai Potensi Kecerdasan Siswa). JURNAL EDUKASI: Jurnal Bimbingan Konseling, Vol. 2(2), 107. https://doi.org/10.22373/je.v2i2.811

Astuti, F. F., \& Zulhakim, A. (2021). Faktor-Faktor yang Mempengaruhi Motivasi Belajar Siswa pada Mata Pelajaran Pendidikan Agama Islam Di SD Negeri 115 Bengkulu Selatan. Jurnal Pendidikan Islam Al-Affan, Vol. 1(2), 8.

Bernadeta, L. S. (2017). Aktualisasi Diri Generasi Y di Instagram. Interaksi: Jurnal Ilmu Komunikasi, Vol. 6(1), 93. https://doi.org/10.14710/interaksi.6.1.93-109

Binbasaran Tuysuzoglu, B., \& Greene, J. A. (2015). An Investigation of The Role of Contingent Metacognitive Behavior in Self-Regulated Learning. Metacognition and Learning, 10(1), 77-98. https://doi.org/10.1007/s11409-014-9126-y

Blakey, E., \& Spence, S. (1990). Developing Metacognition. Eric Digest. Retrived from https://files.eric.ed.gov/fulltext/ED327218.pdf

Bloom, B. S. (Ed.). (nd). Taxonomy of Educational Objectives: The Classification of Educational Goals. Canada: Longmans.

Brookhart, S. M. (2010). How to Assess Higher-Order Thinking Skills in Your Classroom. Alexandria, Va: ASCD.

Chu, H. (2015). Research methods in library and information science: A content analysis. Library \& Information Science Research, 37(1), 36-41. https://doi.org/10.1016/j.lisr.2014.09.003

Danandjaja, J. (2014). Metode Penelitian Kepustakaan. Antropologi Indonesia, Vol. 7(52). https://doi.org/10.7454/ai.v0i52.3318

Deliany, Z., \& Cahyono, B. Y. (2020). Metacognitive Reading Strategies Awareness and Metacognitive Reading Strategies Use Of Efl University Students Across Gender. Studies in English Language and Education, 7(2), 421-437. https://doi.org/10.24815/siele.v7i2.17026

Gardner, H. (2011). Howard Gardner: Frames of Mind The Theory of Multiple Intelligences. New York: Basic Books.

Harahap, N. (2014). Penelitian Kepustakaan. Jurnal Iqra', Vol. 8(01).

Harumi, B. P. Y., \& Marheni, A. (2018). Peran Konsep Diri dan Efikasi Diri Terhadap Kematangan Karier Mahasiswa Fakultas Kedokteran Unviversitas Udayana. Jurnal Psikologi Udayana, Vol. 5(01), 23. https://doi.org/10.24843/JPU.2018.v05.i01.p03

Herlanti, Y. (2015). Kesadaran Metakognitif dan Pengetahuan Metakognitif Peserta Didik Sekolah Menengah Atas dalam Mempersiapkan Ketercapaian Standar Kelulusan pada Kurikulum 2013. Jurnal Cakrawala Pendidikan, 3(3). https://doi.org/10.21831/cp.v3i3.7343

Indarini, E., Sadono, T., \& Onate, M. E. (2013b). Pengetahuan Metakognitif Untuk Pendidik dan Peserta Didik. Satya Widya, Vol. 40. https://doi.org/10.24246/j.sw.2013.v29.i1.p40-46 
Juatiningsih, \& Suendarti, M. (2019). Pengaruh Kecerdasan Intrapersonal dan Kemampuan Berpikir Positif terhadap Kemampuan Penguasaan Konsep Ilmu Pengetahuan Alam (Survei Pada SMP Negeri di Kota Cilegon). Alfarisi: Jurnal Pendidikn MIPA, Vol. 2(1).

Kralik, J. D., Lee, J. H., Rosenbloom, P. S., Jackson, P. C., Epstein, S. L., Romero, O. J., ... McGreggor, K. (2018). Metacognition for a Common Model of Cognition. Procedia Computer Science, 145, 730-739. https://doi.org/10.1016/j.procs.2018.11.046

Krathwohl, D. R. (2002). A Revision of Bloom's Taxonomy: An Overview. Theory Into Practice, 41(4), 212-218. https://doi.org/10.1207/s15430421tip4104_2

Ku, K. Y. L., \& Ho, I. T. (2010). Metacognitive strategies that enhance critical thinking. Metacognition and Learning, Vol. 5(3), 251-267. https://doi.org/10.1007/s11409-0109060-6

Lepskiy, V. (2018). Decision Support Ontologies in Self-Developing Reflexive-Active Environments. IFAC-PapersOnLine, 51(30), 504-509. https://doi.org/10.1016/j.ifacol.2018.11.276

Maryati, T., Khasanah, S. U., \& Maf'ula, V. Y. (2020). Contribution of Teacher's Teaching Skills and Students' Intrapersonal Intelligence Toward Metacognitive Awareness of Students in State Vocational School in Blitar. Journal of Physics: Conference Series, 1470, 012045. Yogyakarta: IOP Science. https://doi.org/10.1088/1742$6596 / 1470 / 1 / 012045$

Marzano, R. J., \& Kendall, J. S. (2007). The new taxonomy of educational objectives (2nd ed). Thousand Oaks, CA: Corwin Press.

Mulyana, B. (2014). Hubungan Konsep Diri, Komitmen, dan Motivasi Berprestasi dengan Prestasi Renang Gaya Bebas. Jurnal Cakrawala Pendidikan, 3(3). https://doi.org/10.21831/cp.v3i3.1636

Nur'aini. (2020). Upaya Meningkatkan Kemampuan Metakognisi Melalui Strategi Pembelajaran PAI Berbasis DDCT Pada Mahasiswa Sekolah Tinggi Agama Islam Ibnu Sina Batam. Jurnal Pendidikan Agama Islam Al-Thariqah, 5(1), 10-18. https://doi.org/10.25299/al-thariqah.2020.vol5(1).4682

Peking, B. S., \& Utami, F. B. (2020). Kecerdasan Intrapersonal Anak Usia 4-5 Tahun: Studi di Tkk 6 Penabur Kelapa Gading, Jakarta Utara. Vol. 01(01), 12.

Pintrich, P. R. (2002). The Role of Metacognitive Knowledge in Learning, Teaching, and Assessing. Taylor \& Francis Group, 41(4,), 219-225.

Sari, D. P., Usodo, B., \& Subanti, S. (2018). Metacognitive Experience of Mathematics Education Students in Open Start Problem Solving Based on Intrapersonal Intelligence. Journal of Physics: Conference Series, 1008, 012062. Jember: IOP Science. https://doi.org/10.1088/1742-6596/1008/1/012062

Sari, M., \& Asmendri. (2020). Penelitian Kepustakaan (Library Research) dalam Penelitian Pendidikan IPA. Natural Science, Vol. 6(1).

Soinbala, H., \& Mulyatna, F. (2019). Penerapan Strategi Pembelajaran Metakognitif dalam Meningkatkan Pemahaman Konsep Matematika. De Fermat: Jurnal Pendidikan Matematika, Vol. 2(1), 46-56. https://doi.org/10.36277/defermat.v2i1.39 
Starkey, L. B. (Ed.). (2010). Reasoning skills success in 20 minutes a day (2nd ed.). New York: LearningExpress.

Stayanchi, J. (2017). Higher-Order Thinking Through Bloom's Taxonomy. Core. Ac.Uk, Vol. 22,8 .

Sugiono. (2013). Metode Penelitian Kuantitatif, Kualitatif, dan A\&D. Bandung: Alfabeta.

Suralaga, F. (2021). Psikologi Pendidikan: Implikasi dalam Pembelajaran. Depok: Rajawali Press.

Werdiningsih, D. (2015). Strategi Metakognisi Pembelajar Anak dalam Pembelajaran Bahasa Indonesia di Sekolah Dasara. (1), 11.

Winne, P. H. (1996). A metacognitive View of Individual Differences in Self-Regulated Learning. Learning and Individual Differences, 8(4), 327-353. https://doi.org/10.1016/S1041-6080(96)90022-9

Copyright Holder :

(C) Ubaidillah, U., Muntoha, T., Khomsinnudin, K., Khasanuddin, M. (2021).

First Publication Right :

(C) Tapis : Jurnal Penelitian Ilmiah

This article is under:

CC BY SA 